\title{
ANALISIS KONDISI PSIKOSEKSUAL TOKOH WARAS \\ DALAM NOVEL TRILOGI RONGGENG DUKUH PARUK \\ KARYA AHMAD TOHARI
}

\author{
Mujihadi \\ SMP Negeri 2 Jatirogo Tuban, mujihadijihad@yahoo.com
}

\begin{abstract}
An analysis in novel of trilogy Ronggeng Dukuh Paruk (RDP) written by Ahmad Tohari focuses on how psychosexual which happen in Waras as the character. This research uses descriptive qualitative method. The purpose of this research is to describe the Waras' psychosexual as the character in the novel which is use the psychological art approach. Psychological art approach is an analysis which focuses on the psychological theory. This analysis model in this novel basically focuses on objective approach. The data in this research is taken from the quotation from the novel $R D P$ which is suitable with research points. After doing the analysis, writer found the psychosexual from the waras as the character. The condition of Waras' psychosexual if related to the Sigmund freud psychosexual development theory, it can be concluded that that psychosexual of Waras was not in appropriate psychosexual development. These psychosexual problems in Waras as character that in his seventeen he still like playing with the younger children, he also like taking care of podang bird just like younger children, and he also is not interested with women.
\end{abstract}

Key words: analysis of psychosexual condition, Waras as the character, Novel of Trilogy Ronggeng Dukuh Paruk.

\section{PENDAHULUAN}

Salah satu karya monumental Ahmad Tohari adalah novel trilogi Ronggeng Dukuh Paruk (RDP). Novel trilogi ini terdiri atas tiga judul novel yaitu Catatan Buat Emak, Lintang Kemukus Dini Hari, dan Jantera Bianglala. Sebagai karya monumental Ahmad Tohari, novel trilogi RDP ini sangat menarik untuk dibaca. Kemenarikan dari novel $R D P$ salah satunya adalah kekuatan dari sang penulis yang mampu menghadirkan penggambaran yang sangat rinci suasana daerah perdesaan. Suasana daerah perdesaan sangat kuat terpotret di sana. Selain kekuatan Ahmad Tohari dalam menggambarkan suasana alam perdesaan, kemenarikan novel trilogi $R D P$ di sisi lainnya adalah kekuatan sang pengarang dalam menghadirkan aspek-aspek kejiwaan dari para tokoh fiksionalnya. 
Berbicara mengenai aspek-aspek kejiwaan yang ada dalam tokoh fiksional yang dicipta pengarang, maka karya sastra ini akan dianalisis dengan menggunakan pendekatan psikologi sastra. Psikologi sastra adalah sebuah interdisiplin antara psikologi dan sastra (Endraswara, 2008:16). Permasalahan yang dianalisis dalam penelitian ini adalah: pertama, bagaimana identitas dan ciri fisik tokoh fiksional Waras; kedua, bagaimana kondisi psikoseksual tidak lazim tokoh fiksional Waras yang terdapat dalam novel trilogi RDP karya Ahmad Tohari. Dengan demikian, maka tujuan dari pembahasan ini adalah: pertama, mendeskripsikan tentang identitas dan ciri fisik tokoh fiksional Waras; kedua, mendeskripsikan kondisi psikoseksual tidak lazim tokoh fiksional Waras dalam novel trilogi RDP karya Ahmad Tohari.

Terdapat berbagai definisi tentang psikologi sastra, di antaranya adalah sebagai berikut. Endraswara (2008:16) mengatakan bahwa psikologi sastra adalah interdisiplin antara psikologi dan sastra. Hartoko dan Rahmanto (1986:126 - 127) mengemukakan bahwa psikologi sastra merupakan cabang ilmu sastra yang mendekati sastra dari sudut psikologi. Perhatiannya dapat diarahkan pada pengarang, pembaca, atau kepada teks itu sendiri. Wiyatmi (2011:6) mendefinisikan psikologi sastra sebagai salah satu jenis kajian dalam sastra yang digunakan untuk membaca dan menginterpretasikan karya sastra, pengarang karya sastra, dan pembaca karya sastra dengan menggunakan berbagai konsep dan kerangka teori yang ada dalam psikologi. Dengan demikian dapat dikatakan bahwa psikologi sastra adalah interdisiplin antara psikologi dan sastra; ia merupakan cabang ilmu yang berusaha mendekati sastra dari sudut psikologi; digunakan untuk menginterpretasikan karya sastra, pengarang karya sastra, dan pembaca karya sastra dengan menggunakan berbagai konsep dan kerangka teori yang ada dalam psikologi.

Kajian psikologi sastra tentu memiliki tujuan tertentu. Secara definitif, tujuan psikologi sastra seperti yang dikemukakan oleh Ratna (dalam Minderop, 2011:54) adalah untuk memahami aspek-aspek kejiwaan yang terkandung di dalam suatu karya. Ada tiga macam cara yang dapat dilakukan untuk memahami hubungan antara psikologi dan sastra, yaitu: pertama, memahami unsur-unsur kejiwaan pengarang sebagai penulis; kedua, memahami unsur-unsur kejiwaan para tokoh fiksional dalam karya sastra, dan; ketiga, memahami unsur-unsur kejiwaan pembaca. Lebih lanjut dikatakan oleh Ratna (dalam Minderop, 2011:54), bahwa pada dasarnya psikologi sastra memberikan perhatian pada masalah kejiwaan para tokoh fiksional yang terkandung dalam karya sastra. Adapun dalam analisis novel trilogi RDP karya Ahmad Tohari ini, peneliti akan mengaji novel ini 276 | E-ISSN: 2527-8754 http:// journal.unesa.ac.id/index.php/Paramasastra 
dengan menggunakan pendekatan dari pengertian yang kedua, yaitu, penelitian akan terfokus pada teks karya sastra yang dikaji dengan menggunakan pendekatan hukumhukum psikologi.

Membicarakan masalah psikoseksual sebenarnya adalah membahas masalah bertumbuh-kembangnya kepribadian - sejalan dengan pertumbuhan dan perkembangan tubuh - di mana faktor seksualitas memainkan peranan kunci (Arif, 2006:45). Selanjutnya berkait dengan teori perkembangan psikoseksual, Hariyanto (2010) menyatakan bahwa teori perkembangan psikoseksual Freud adalah salah satu teori yang paling terkenal sekaligus kontroversial. Freud percaya bahwa kepribadian yang berkembang melalui serangkaian tahapan pada masa anak-anak - di mana individu selalu mencari kesenangan energi dari $i d$ - akan menjadi fokus pada area sensitif seksual tertentu. Energi psikoseksual, atau libido, digambarkan sebagai kekuatan pendorong di belakang perilaku. Menurut Freud, kepribadian sebagian besar dibentuk pada usia lima tahun pertama. Awal perkembangan tersebut akan berpengaruh besar terhadap pembentukan kepribadian dan secara terus-menerus akan memengaruhi perilaku individu di kemudian hari. Jika tahaptahap psikoseksual selesai dengan sukses, hasilnya adalah kepribadian yang sehat.

Freud (dalam Arif, 2006:46) membagi perkembangan psikoseksual menjadi lima fase. Kelima fase itu adalah sebagai berikut. Pertama, usia $0-1.5$ tahun disebut sebagai Fase Oral. Kedua, usia 1.5 - 3 tahun disebut sebagai Fase Anal. Ketiga, usia 3 - 5 tahun disebut sebagai Fase Phallic. Keempat, usia 5 - 12 tahun/pubertas disebut sebagai Fase Latent. Kelima, usia 12 tahun/pubertas - seterusnya disebut sebagai Fase Genital. Selanjutnya kelima tahap perkembangan psikoseksual tersebut akan dibicarakan secara singkat pada penjelasan berikut.

Fase Oral merupakan fase pertama perkembangan psikoseksual bayi. Objek pertama yang menyapa bayi dan menjalin relasi dengannya tidak lain adalah ibu - lebih spesifik lagi adalah payudara ibu (Arif, 2006:49). Disebut sebagai fase oral karena di sini bayi membangun relasi pertama dengan realitas eksternal adalah dengan cara menyusu/oral. Fase Anal; pada tahap ini, Freud percaya bahwa fokus utama dari libido adalah pada pengendalian kandung kemih dan buang air besar. Konflik utama pada tahap ini adalah pelatihan toilet - anak harus belajar untuk mengendalikan kebutuhan tubuhnya. Keberhasilan pada tahap ini tergantung pada di mana cara pendekatan orang tua terhadap pelatihan toilet. Orang tua yang memanfaatkan pujian dan penghargaan untuk 
menggunakan toilet pada saat yang tepat mendorong hasil positif dan membantu anakanak merasa mampu dan produktif (Hariyanto, 2010).

Fase Phallic; pada tahap ini fokus utama dari libido adalah pada alat kelamin. Perkembangan terpenting dalam fase ini adalah munculnya oedipus complex, yang diikuti oleh fenomena castration anxiety (pada laki-laki) dan penis envy (pada perempuan). Odipus kompleks adalah kateksis objek seksual kepada kepada orang tua yang berlawanan jenis serta permusuhan terhadap orang tua sejenis. Anak laki-laki ingin memiliki ibunya dan menyingkirka ayahnya; sebaliknya anak perempuan ingin memiliki ayahnya dan meyingkirkan ibunya. Pada awalnya baik anak perempuan maupun laki-laki sama-sama mencintai ibunya karena telah memenuhi semua kebutuhan mereka dan memandang ayah sebagai saingan dalam merebut kasih sayang ibu. Namun, bedanya adalah; pada anak laki-laki persaingan dengan ayahnya itu akan mengakibatkan dia cemas penisnya akan dipotong sang ayah, sedangkan pada anak perempuan, rasa cinta kepada ibunya segera berubah menjadi kecewa setelah mengetahui bahwa kelaminnya berbeda dengan anak laki-laki sehingga ibunya dianggap bertanggung jawab atas kastrasi kelaminnya (Alwisol, 2008:31-32).

Fase Laten; periode ini memunyai ciri-ciri bahwa dorongan libidinal biasanya mengalami represi yang cukup efektif. Dorongan libidinal pada saat ini seolah "tidur" dan akan bengkit lagi dengan kekuatan penuh kelak di masa pubertas tiba. Selajutnya dikatakan Arif (2006:66 - 67) bahwa terjadi perkembangan kognitf dan sosialisasi anak yang pesat. Rasa ingin tahu anak sangat besar tentang berbagai hal. Oleh karena itu penting sekali orang tua memenuhi rasa ingin tahu dari anak tersebut. Usaha yang dapat dilakukan adalah dengan menyediakan pendidikan yang baik untuk memenuhi kebutuhan anak. Fase Genital; fase ini adalah tahap akhir perkembangan psikoseksual. Pada fase ini pula seorang individu akan mengembangkan minat seksual yang kuat pada lawan jenis. Pada fase ini seseorang akan mengalami perubahan yang sangat besar dan cepat dalam diri dan dunianya. Tinggi dan berat badannya akan meningkat tajam. Ciri-ciri seksual primer dan sekunder akan mulai muncul. Dorongan libidinal dalam fase ini akan meningkat dengan pesat (Arif, 2006:67).

Penelitian terhadap novel trilogi $R D P$ ini adalah jenis penelitian deskriptif kualitatif yang selanjutnya disebut penelitian kualitatif. Sumber data penelitian ini adalah novel trilogi RDP karya Ahmad Tohari yang diterbitkan Gramedia Pustaka Tama Jakarta cetakan ketujuh tahun 2011. Novel tersebut memunyai ukuran dua puluh satu $\mathrm{x}$ lima belas cm dengan tebal buku 406 halaman. Data dalam penelitian ini berupa kutipan 278 | E-ISSN: 2527-8754 http:// journal.unesa.ac.id/index.php/Paramasastra 
kata-kata, kalimat, frasa, paragraf, dan wacana yang berasal dari novel trilogi $R D P$ di mana teks tersebut memiliki keterkaitan dengan fokus pembahasan dalam penelitian ini.

Model analisis novel trilogi $R D P$ ini menggunakan pendekatan psikologi sastra. Pendekatan psikologi sastra ini merupakan interdisipliner antara psikologi dan sastra yaitu model pendekatan yang menganalisis karya sastra dengan cara mengaitkan antara karya sastra dengan disiplin ilmu yang lain, yaitu ilmu psikologi. Jadi, pendekatan ini menggunakan dua disiplin ilmu sekaligus. Hal ini sejalan dengan pernyataan Sudikan (2015:230) yang mengatakan bahwa penelitian interdisiplin secara definitif adalah jenis penelitian yang dalam proses analisisnya menyarankan untuk melibatkan dua bidang ilmu atau lebih.

Ada tiga macam pendekatan yang dapat dilakukan untuk memahami hubungan antara psikologi dan sastra. Pertama, pendekatan tekstual, yang mengaji aspek psikologi tokoh dalam karya sastra. Kedua, pendekatan reseptif-pragmatik, yang mengaji aspek psikologi pembaca sebagai penikmat karya sastra. Ketiga, pendekatan ekpresif, yang mengaji aspek psikologi sang penulis ketika mencipta karya sastra (Endraswara, 2011:97 - 98). Adapun model analisis yang dimanfaatkan oleh peneliti dalam menganalisis novel trilogi $R D P$ ini adalah dengan cara yang pertama, yaitu pendekatan tekstual yang mengaji aspek psikologi tokoh dalam karya sastra. Model analisis yang difokuskan pada karya sastra ini pada dasarnya merupakan model penelitian yang lebih dekat dengan pendekatan objektif (Ratna, 2013:61). Karena analisis terhadap karya sastra ini menggunakan model analisis interdisipliner psikologi sastra maka data yang berupa kutipan kata-kata, kalimat, frasa, paragraf, dan wacana yang memiliki keterkaitan dengan fokus masalah dalam penelitian ini selanjutnya akan dimaknai dan dikaitkan dengan hukum-hukum dalam disiplin psikologi.

\section{PEMBAHASAN}

Pada bagian pembahasan ini peneliti akan membahas dua permasalahan yang ada dalam penelitian ini. Seperti telah disebutkan di bagian awal tulisan ini bahwa fokus penelitian ini adalah; pertama, bagaimana identitas dan ciri fisik tokoh fiksional Waras; kedua, bagaimana kondisi psikoseksual tidak lazim tokoh fiksional Waras dalam novel RDP karya Ahmad Tohari. Untuk mempermudah menjawab permasalahan yang ada dalam fokus penelitian, maka pembahasan ini dibagi dalam dua kelompok. Kedua kelompok itu adalah sebagai berikut. Pertama; membahas tentang identitas dan ciri fisik 
tokoh fiksional Waras. Kedua; membahas tentang kondisi psikoseksual tidak lazim tokoh fiksional Waras. Adapun pembahasan selengkapnya akan diuraikan peneliti dalam analisis di bawah ini.

Identitas dan Ciri Fisik Tokoh Fiksional Waras

Yang dimaksud oleh peneliti dengan istilah identitas dari tokoh fiksional Waras di sini adalah deskripsi tentang usia tokoh fiksional tersebut. Sedangkan ciri-ciri fisik maksudnya adalah ciri-ciri lahir atau badaniah yang melekat pada diri tokoh fiksional Waras. Deskripsi tentang identitas dan ciri fisik tokoh fiksional Waras ini perlu dianalisis oleh peneliti sebab dengan deskripsi tersebut maka peneliti akan lebih mudah dalam proses analisis selanjutnya.

Dari hasil analisis terhadap teks novel RDP penulis memeroleh data bahwa tokoh fiksional Waras adalah seorang pemuda dari desa Alaswangkal yang sudah berusia tujuh belas tahun. Hal itu terlihat dari percakapan antara tokoh Sentika (ayah Waras) dan Sakarya (kakek Srintil) ketika mereka bermaksud menanggap ronggeng. Saat itu Sentika bermaksud akan menanggap ronggeng karena dulu dia telanjur pernah kaul (nazar) bahwa jika Waras memang sehat sampai dewasa maka dia akan mementaskan ronggeng terbaik untuk Waras. Gambaran tentang tokoh fiksional Waras yang sudah berumur tujuh belas tahun tersebut dapat dibuktikan pada teks novel trilogi $R D P$ berikut ini.

"Anakku berjumlah empat belas orang, tetapi hanya dua yang laki-laki. Itu pun di antaranya meninggal ketika masih kecil. Jadi tinggal si Waras seorang anak laki-lakiku. Semata wayang. Si Waras kini sudah tujuh belas tahun (Tohari, 2011:200 - 201)."

Dari data tersebut peneliti juga memeroleh informasi bahwa tokoh fiksional Waras merupakan satu-satunya anak laki-laki yang hidup di antara dua belas saudaranya yang perempuan. Sebenarnya tokoh Waras pernah memunyai satu saudara laki-laki, tapi saudara laki-lakinya itu sudah meninggal dunia ketika masih kecil. Jadi dengan demikian maka tokoh Waras dalam menjalani hidup selama tujuh belas tahun dia hidup dalam keluarga yang didominasi oleh para perempuan. Satu-satunya teman hidup laki-laki di dalam keluarga Waras adalah Sentika (ayahnya). Menjalani hidup dengan dua orang tua dan dua belas saudara yang semunya perempuan tentu merupakan hal unik. Hal ini tentu akan berpengaruh besar terhadap perkembangan kepribadian seorang anak.

Selanjutnya, untuk memeroleh gambaran fisik dari tokoh fiksional Waras dapat dijelaskan sebagai berikut. Tokoh Waras digambarkan sebagai seorang pemuda yang telah berusia tujuh belas tahun dan berbadan kurus. Tubuh Waras yang kurus 280 | E-ISSN: 2527-8754 http:// journal.unesa.ac.id/index.php/Paramasastra 
digambarkan sebagai tubuh yang tipis, pundak kurus, dan sempit. Adapun gambaran fisik mengenai tinggi badan, tokoh Waras digambarkan sebagai pemuda yang jangkung. Jadi, gambaran fisik tokoh Waras dapat dikatakan memunyai badan yang kurus dan jangkung. Selain itu Waras digambarkan juga sebagai pemuda yang lemah/tidak punya tenaga. Semua gambaran tentang keadaan fisik tokoh Waras tersebut di dalam teks novel trilogi $R D P$ dilukiskan dengan kalimat berikut.

"Waras bertubuh tipis, jangkung. Dan kelihatan lebih jangkung dengan pakaiannya yang terdiri atas kaus singlet dan celana setinggi lutut.//...// Pundaknya kurus dan sempit. Tanggannya mirip sepasang seruling, kuning pucat dan tanpa otot. Dan rupanya sepasang kaki itu hanya tumbuh memanjang dan memanjang, tidak pernah bertambah besar (Tohari, 2011:211)."

Diksi yang dipilih Ahmad Tohari dalam menggambarkan tokoh Waras sangat tepat. Tangannya mirip sepasang seruling, tanpa otot, bertubuh tipis, jangkung, dan pundaknya yang kurus serta sempit, semuanya semakin menegaskan deskripsi keadaan fisik tokoh Waras. Yaitu menggambarkan seorang pemuda yang telah berumur tujuh belas tahun, tinggi, kurus, dan tidak memunyai tenaga. Gambaran tentang identitas dan ciri-ciri fisik tokoh fiksional Waras di atas, jika dikaitkan dengan teori perkembangan psikoseksual Sigmund Freud, maka dapat dikatakan sebagai sebuah kondisi psikoseksual yang menyimpang. Dikatakan menyimpang karena dalam kondisi ideal maka kondisi psikoseksual tokoh Waras pada saat itu seharusnya meningkat tajam. Sebagaimana kita ketahui dari teori perkembangan psikoseksual Sigmund Freud yang menyatakan bahwa pada fase genital ini kondisi perkembangan tubuh akan mengalami perkembangan yang meningkat tajam baik tinggi maupun berat badan (Arif, 2006:67). Di dalam teks itu digambarkan bahwa tokoh Waras badannya hanya memanjang saja namun berat badanya tidak pernah bertambah. Kondisi fisik Waras seharusnya berkembang pesat baik tinggi maupun berat badannya. Demikian juga dengan kondisi kekuatan badannya, idealnya tokoh Waras itu seharusnya kuat bertenaga. Tidak seperti yang digambarkan, yaitu seorang pemuda yang lemah tidak bertenaga. Hal yang demikian semakin menegaskan bahwa kondisi fisik tokoh Waras telah mengalami penyimpangan perkembangan.

\section{Kondisi Psikoseksual Tidak Lazim Tokoh Fiksional Waras}

Berdasarkan analisis data pada novel trilogi $R D P$ peneliti memeroleh dua macam informasi tentang kondisi psikoseksual tidak lazim yang dialami tokoh fiksional Waras. Kondisi psikoseksual tidak lazim yang dialami oleh tokoh Waras adalah sebagai berikut. 
Pertama; tokoh Waras masih suka bermain-main dengan anak-anak dan suka memelihara burung podang. Kedua; tokoh Waras tidak memunyai ketertarikan/nafsu berahi terhadap lawan jenis. Untuk memeroleh gambaran yang lebih jelas tentang hal tersebut, peneliti akan menguraikan lebih lengkap pada bagian di bawah ini.

Suka bermain dengan anak-anak dan memelihara burung podang

Kondisi tokoh Waras dikatakan tidak lazim karena di usianya yang sudah berumur tujuh belas tahun dia masih suka bermain dengan anak-anak kecil. Keadaan yang wajar adalah bahwa dia seharusnya bermain/bersahabat dengan teman sebaya. Keadaan tentang kebiasaan tokoh Waras ini membuat Srintil terheran-heran. Srintil terperangah dan heran melihat tingkah laku Waras yang tidak lazim itu. Keadaan tokoh Waras yang demikian itu membuyarkan angan-angan Srintil tentang tokoh Waras yang baru dikenalnya. Adapun gambaran tentang tokoh Waras yang masih suka bermain-main dengan anak kecil ini terdapat di dalam novel trilogi $R D P$ seperti teks berikut ini.

"Di sana, kira-kira dua puluh meter dari jendela, Srintil melihat seorang anak muda datang diiringi seorang anak kecil. Kesan pertama langsung membuyarkan angan-angan Srintil (Tohari, 2011:211).”

Gambaran lainnya yang menunjukkan bahwa tokoh Waras masih suka bermainmain dengan anak kecil adalah ketika dia mencari belalang untuk disuapkan pada anak burung podang yang dipeliharanya. Ketika bermain dan mencari belalang tokoh Waras selalu ditemani oleh anak-anak kecil. Kebiasaan tidak lazim dari tokoh Waras ini digambarkan dalam teks novel trilogi $R D P$ seperti terlihat dalam dialog antara Waras dan Srintil berikut ini.

"Aku sudah punya teman. Banyak sekali. Mereka membantu mencari belalang untuk makan burungku. "Ah, itu kan teman kecil-kecil (Tohari, 2011:214)."

Kata-kata yang diucapkan tokoh Waras kepada Srintil bahwa dia sudah memunyai banyak teman dan jawaban Srintil yang mengatakan bahwa teman Waras adalah anak-anak kecil semakin menegaskan gambaran tidak lazim perilaku tokoh Waras. Yaitu gambaran seorang pemuda berusia tujuh belas tahun namun masih suka bermain dengan anak-anak kecil.

Suka memelihara anak burung podang adalah gambaran dari kondisi psikoseksual yang tidak lazim berikutnya dari tokoh Waras. Di usianya yang sudah mencapai tujuh belas tahun tokoh Waras masih suka memelihara anak burung podang. Kebiasaan memelihara dan menyuapi anak burung podang adalah kebiasaan yang hanya umum 
dilakukan oleh anak kecil. Gambaran tentang tokoh Waras yang masih suka memelihara anak burung podang digambarkan dalam novel trilogi $R D P$ seperti pada teks berikut.

"Bila benar Waras berusia tujuh belas, maka wajahnya jauh lebih muda. Belum jelas kelelakiannya. Dan yang hampir takbisa dimengerti oleh Srintil adalah sesuatu yang kelihatan amat disayang oleh perjaka Alaswangkal ini. Seekor anak burung podang (Tohari, 2011:211)."

Di dalam teks tersebut juga disebutkan bahwa kebiasaan tokoh Waras memelihara anak burung podang tidak bisa dipahami oleh Srintil. Bagi Srintil, adalah merupakan hal yang sangat aneh jika seorang perjaka masih suka memelihara anak burung podang. Dalam pandangan Srintil, gemar memelihara anak burung podang adalah hanya umum terjadi pada anak kecil saja dan bukan terjadi pada seorang perjaka seperti tokoh Waras. Penggambaran yang ditulis oleh Ahmad Tohari dalam novel trilogi RDP tentang perilaku Srintil menertawai Waras adalah bukti bahwa Srintil memang geli dan heran melihat perilaku Waras. Gambaran dari keheranan Srintil tentang kegemaran Waras yang masih suka memelihara anak burung podang tersebut digambarkan oleh Ahmad Tohari dalam novel trilogi $R D P$ seperti teks berikut.

"Di Dukuh Paruk, Srintil biasa melihat anak burung dipelihara oleh manusia. Tetapi manusia kecil sepuluh tahunan, bukan perjaka jangkung seperti Waras. Ketika melihat bagaimana Waras menyuapi burungnya dengan seekor belalang, Srintil lalu berbalik. Diam sesaat sambil menatap Nyai Kartareja. Bibirnya bergerak-gerak dan menyusul ledakan tawanya (Tohari, 2011:211).”

Masih suka bermain dengan anak-anak dan gemar memelihara anak burung podang adalah cermin diri perilaku tokoh Waras yang tidak lazim. Perilaku tokoh Waras yang digambarkan oleh Ahmad Tohari dalam novel trilogi RDP ini sebenarnya hanya cocok sebagai bentuk perilaku yang umum ditunjukkan oleh seorang anak kecil dan tidak lazim untuk seorang perjaka seusia Waras. Di usianya yang telah melewati usia tujuh belas tahun seharusnya perilaku Waras tidak demikian. Seharusnya dalam kondisi yang ideal tokoh Waras sudah memiliki identitas diri yang baru dan meninggalkan dunia anakanak menuju ke dunia remaja. Perilaku Waras ini dapat diindikasikan sebagai gangguan mental/psikopatologi. Hal ini senada dengan Erik H. Erikson (dalam Arif, 2006:68) yang menyatakan bahwa ketika pada fase genital ini seharusnya anak sudah beralih dari dunia anak-anak ke dunia remaja. Anak remaja dalam fase ini seharusnya sedang merajut identitas dirinya yang baru karena identitas anak-anaknya sudah tidak memadai lagi. 
Selanjutnya juga dikatakan oleh Arif bahwa dengan segala perubahan tubuh, kognisi dan sosialnya, fase genital adalah masa yang kritis. Pada fase ini remaja dapat memasuki dan mengalami integrasi yang penuh dalam kepribadiannya. Namun, bisa juga karena kerapuhan kepribadiannya, maka ia dapat mengalami berbagai konflik yang pada akhirnya dapat mengakibatkan psikopatologi (2006:68)

Tidak ada ketertarikan/nafsu berahi terhadap lawan jenis

Kondisi psikoseksual tidak lazim dari tokoh Waras berikutnya adalah tidak adanya rasa tertarik/nafsu berahi terhadap lawan jenis. Tidak adanya ketertarikan/nafsu berahi pada lawan jenis pada diri tokoh Waras ditunjukkan oleh Ahmad Tohari dalam novel trilogi $R D P$ ketika menceritakan tokoh Srintil saat menjadi gowok bagi Waras. Perlu diketahui bahwa gowok adalah seorang wanita yang biasanya disewa oleh orang tua dari anak laki-laki yang akan menjalani pernikahan.

Fungsi gowok adalah mengajari anak laki-laki yang akan menikah tersebut sehingga nanti dia siap secara lahir batin mengarungi kehidupan berkeluarga. Di sini tugas gowok antara lain adalah memberi pelajaran tentang hidup berumah tangga. Namun, lebih dari semua itu tugas seorang gowok yang paling inti adalah mempersiapkan perjaka yang akan menikah agar tidak mendapat malu saat menghadapi malam pengantin baru.

Gowok ini biasanya adalah seorang janda atau perempuan penjaja diri. Memang kadang kala ada suami yang merelakan istrinya menjadi gowok, namun hal ini jarang sekali terjadi. Masa pergowokan biasanya hanya berlangsung beberapa hari, paling lama sepekan. Gambaran tentang gowok dan tugas-tugasnya tersebut dapat kita jumpai dalam novel trilogi $R D P$. Hal tersebut telah digambarkan secara menarik oleh Ahmad Tohari seperti pada teks berikut ini.

"Bahwa gowok adalah seorang perempuan yang disewa oleh seorang ayah bagi anak lelakinya yang sudah dewasa. Dan menjelang kawin. Seorang gowok akan memberi pelajaran kepada anak laki-laki banyak hal perikehidupan berumah tangga. //.../. Satu hal yang tidak perlu diterangkan tetapi harus diketahui oleh semua orang adalah hal menyangkut tugas inti seorang gowok. Yaitu mempersiapkan seorang perjaka agar tidak mendapat malu pada malam pengantin baru (Tohari, 2011:201).”

Digambarkan juga dalam novel itu bahwa ketika Srintil menjadi gowok bagi Waras, tokoh Srintil tidak merasakan adanya gairah berahi muncul pada diri tokoh Waras. Pada diri Waras tidak ada ketertarikan terhadap diri Srintil. Gambaran tentang tidak 
adanya rasa tertarik/nafsu berahi dalam diri Waras terhadap Srintil ditunjukkan dalam novel trilogi $R D P$ seperti pada teks berikut.

"Waras bangkit memeluk Srintil, mendekapnya dan menciuminya. Srintil pasrah saja. Atau geli. Tak ada rangsangan berahi (Tohari, 2011:214)."

Dari data teks di atas kita mengetahui bahwa tokoh Waras memang tidak memunyai rasa tertarik/nafsu berahi terhadap lawan jenis. Hal demikian justru dapat kita ketahui dari apa yang dirasakan oleh Srintil. Saat itu Srintil berjanji kepada Waras bahwa jika dia (Waras) mau diajak menari maka nanti akan diberi hadiah yaitu dapat tidur dengannya. Reaksi Waras saat itu memang senang. Tapi rasa senang yang ditunjukkan oleh Waras itu adalah rasa senang karena ia memandang tidur dengan Srintil sama dengan ketika tidur bersama ibunya. Maka yang terjadi adalah bahwa Waras hanya memeluk dan mencium Srintil tanpa adanya rangsangan nafsu berahi yang muncul dalam dirinya. Gambaran lainnya tentang tokoh Waras yang tidak memunyai rasa tertarik/nafsu berahi terhadap lawan jenis dapat kita cermati dari data teks berikut.

"Tetapi yang terbaca dari wajah Waras adalah sikap memustahilkan hubungan ragawi antara dua manusia lelaki dan perempuan, apa pun namanya (Tohari, 2011:223 - 224)."

Diksi yang dipilih Ahmad Tohari dengan kalimat "sikap memustahilkan hubungan ragawi antara dua manusia lelaki dan perempuan" dalam menggambarkan perilaku tidak lazim dari seorang perjaka terasa amat tepat. Diksi ini dengan sangat jelas menggambarkan perilaku tokoh Waras yang tidak memunyai ketertarikan berahi dengan seorang wanita. Dengan tidak adanya ketertarikan berahi terhadap seorang wanita maka yang akan terjadi adalah memustahilkan hubungan badaniah (sanggama) antara tokoh Waras dan Srintil.

Tingkah laku tokoh Waras ketika berada di kamar tidur bersama Srintil pun dimaknai Waras hanya seperti tidur bersama ibunya saja (bukan seperti sepasang kekasih). Seperti layaknya seorang anak kecil terhadap ibunya - di saat Srintil mengajak tidur berdua - Waras hanya bermain kutang serta memijit-mijit puting susu Srintil. Hal serupa itulah yang sering kali dilakukan oleh tokoh Waras ketika tidur bersama ibunya. Gambaran tentang perilaku tidak lazim dari tokoh Waras yang menganggap tidur berdua dengan Srintil sama dengan ketika tidur bersama ibunya itu digambarkan dalam novel trilogi $R D P$ seperti teks berikut. 
"Tetapi Srintil berhasil membawa Waras masuk ke kamar, mengajaknya bermain tidur-tiduran. Konsep tentang tidur bagi Waras terlalu sederhana. Yakni merebahkan diri di samping Emak, miring-meringkuk. Tangan kanan bersembunyi di pangkal ketiak Emak dan tangan kiri bermain kain kutangnya. Atau memijit-mijit puting teteknya. Dan demikian jugalah yang dilakukan terhadap Srintil (Tohari, 2011:222).”

Diksi bermain kutang dan memijit puting teteknya yang dipilih Ahmad Tohari dalam menggambarkan perilaku tokoh Waras ketika tidur berdua dengan Srintil ini terasa sangat tepat. Diksi ini tidak hanya mampu menggambarkan tokoh Waras sebagai seorang pemuda yang tidak punya ketertarikan/nafsu berahi terhadap wanita, namun lebih dari itu diksi ini juga mampu menggambarkan perilaku Waras yang masih kekanak-kanakan. Kita sering melihat ketika anak kecil sedang menyusu ibunya biasanya memang menunjukkan perilaku yang demikian. Yaitu bermain tali kutang dan sering memijit puting susu ibunya.

Gambaran tentang tokoh Waras yang tidak memunyai ketertarikan/nafsu berahi terhadap lawan jenis juga terdapat dalam teks lainnya. Di dalam teks itu Ahmad Tohari menggambarkan tokoh Waras sebagai tokoh yang telah tersingkir dari dunia kelelakian dan menghadapi malapetaka kejiwaan. Diksi tersingkir dari identitas kelelakiannya, seorang perjaka yang tumbuh dalam malapetaka kejiwaan ini memang sengaja dipilih penulis novel. Hal ini dilakukan penulis novel untuk menegaskan gambaran perilaku Waras yang tidak memunyai ketertarikan terhadap lawan jenis. Adapun gambaran tersebut tampak pada novel trilogi $R D P$ seperti pada teks berikut.

"Ketika memutuskan menjadi gowok bagi Waras maka timbul kesadaran baru di hati Srintil. Bahwa dirinya adalah perempuan dalam falsafah yang amat dalam. Perempuan yang harus mampu berperan banyak di hadapan seorang laki-laki muda yang nyaris tersingkir dari identitas kelelakiannya, seorang perjaka yang tumbuh dalam malapetaka kejiwaan (Tohari, 2011:216).”

Kondisi psikoseksual yang dialami oleh tokoh Waras ini jika dikaitkan dengan teori perkembangan psikoseksual Sigmund Freud merupakan penyimpangan. Dikatakan demikian karena pada fase genital (tujuh belas tahun usia Waras) ini seharusnya tokoh Waras memunyai rasa tertarik/nafsu berahi yang besar terhadap Srintil. Seperti yang telah dikatakan oleh Sigmund Freud (dalam Arif, 2006:67) bahwa dalam fase ini ciri-ciri seksual primer dan sekunder akan mulai muncul dan dorongan libidinal dalam fase ini akan meningkat dengan pesat. Hal ini bertolak belakang dengan apa yang dialami oleh tokoh Waras. Di dalam teks novel trilogi RDP digambarkan bahwa Waras bukan hanya 286 | E-ISSN: 2527-8754 http:// journal.unesa.ac.id/index.php/Paramasastra 
tidak memunyai ketertarikan/nafsu berahi terhadap lain jenis. Namun, yang lebih tragis lagi adalah ternyata Waras telah kehilangan dunia kelelakiannya dan tidak akan sanggup menemukannya kembali. Gambaran tentang hal tersebut ditulis Ahmad Tohari dalam novel trilogi $R D P$ seperti pada teks berikut ini.

"Srintil harus menelan ludah berkali-kali karena harus meyakini keadaan Waras,

dia benar-benar hilang dari dunia kelelakian dan Srintil pasti taksanggup lagi

menemukannya kembali (Tohari, 2011: 224)."

Diksi dia benar-benar hilang dari dunia kelelakian dan Srintil pasti taksanggup lagi menemukannya kembali, jika dikaitkan denga teori perkembangan psikoseksual Sigmund Freud dapat dikatakan bahwa tokoh Waras telah mengalami psikopatologi (penyimpangan/gangguan mental) jenis psikosis. Sebagamana kita ketahui bahwa jenis psikopatologi ada empat tingkatan. Secara berturut-turut keempat tingkatan psikopatologi itu adalah: pertama, personality disturbances; kedua, neurosis; ketiga, personality disorders (psychopath); dan keempat, psikosis (Arif, 2006:70). Selanjutnya dikatakan oleh Arif bahwa penderita psikosis dapat diibaratkan seperti rumah yang sudah runtuh. Rumah tersebut sudah hancur berserakan sehingga nyaris tidak bisa melindungi penghuninya lagi. Rumah seperti itu bisanya memang tidak kokoh bangunannya, sehingga tidak kuat ketika menghadapi terpaan angin dan hujan. Psikosis adalah jenis psikopatologi yang paling berat (2006:71 - 78). Keadaan psikoseksual seperti itulah yang dialami tokoh Waras. Yaitu seorang tokoh fiksional yang digambarkan oleh pengarang novel sebagai individu yang telah mengalami malapetaka kejiwaan dan Srintil tidak akan mampu menemukannya kembali.

\section{SIMPULAN}

Dari pembahasan mengenai kondisi psikoseksual tokoh fiksional Waras dalam novel trilogi Ronggeng Dukuh Paruk karya Ahmad Tohari dapat disimpulkan sebagai berikut. Tokoh fiksional Waras merupakan seorang remaja yang telah berumur tujuh belas tahun. Kondisi psikoseksual tokoh fiksional Waras menampakkan hal-hal yang tidak lazim. Ketidaklaziman perilaku Waras ditunjukkan Ahmad Tohari ketika menggambarkan tokoh Waras yang di usianya yang sudah mencapai tujuh belas tahun namun masih suka bermain dengan anak-anak kecil dan suka memelihara anak burung podang. Ketidaklaziman perilaku tokoh fiksional Waras yang paling tragis adalah tidak adanya rasa tertarik/nafsu berahi terhadap lawan jenis (wanita). Kondisi psikoseksual 
yang dialami oleh tokoh Waras ini jika dikaitkan dengan teori perkembangan psikoseksual Sigmund Freud merupakan gangguan mental/psikopatologi jenis psikosis.

Penelitian terhadap novel trilogi $R D P$ karya Ahmad Tohari ini hanya berfokus mengaji pada bagaimana kondisi psikoseksual tokoh fiksional Waras dengan menggunakan tinjauan psikologi sastra. Oleh karena itu peneliti menyarankan kepada para peneliti berikutnya agar berkenan melakukan penelitian lanjutan dengan fokus dan model penelitian psikologi sastra lainnya. Misalnya, penelitian dapat diarahkan pada bagaimana kondisi kejiwaan tokoh Srintil jika dikaji dengan teori kebutuhan bertingkat dari Abraham Maslow; bagaimana kondisi kejiwaan tokoh Rasus jika ditinjau dari psikologi kepribadian Sigmund Freud; dan lain sebagainya. Selain itu peneliti juga menyarankan agar novel ini dianalisis dengan model pendekatan interdispliner lainnya. Dengan demikian maka khazanah kritik sastra terhadap novel trilogi $R D P$ ini akan semakin lengkap sehingga pada akhirnya teks sastra sebagai suatu dokumen kebudayaan dari suatu bangsa dapat termanfaatkan secara lebih baik.

\section{DAFTAR RUJUKAN}

Alwisol. 2008. Psikologi Kepribadian. Malang: UPT Penerbitan Universitas Muhammadiyah Malang.

Arif, Iman Setiadi. 2006. Dinamika Kepribadian, Gangguan dan Terapinya. Bandung: Refika Aditama.

Endraswara, Suwardi. 2008. Metode Penelitian Psikologi Sastra; Teori, Langkah, dan Penerapannya. Yogyakarta: FBS Universitas Negeri Yogyakarta. . 2011. Metodologi Penelitian Sastra; Epistemologi, Model, Teori, dan Aplikasi. Yogyakarta: CAPS.

Hariyanto. 2010. Tahap Perkembangan Psikoseksual Sigmund Freud. Tersedia: http://belajarpsikologi.com/tahap-perkembangan-psikososial-menurutsigmund-freud/ diunduh : Kamis, 21 Januari 2016 pukul 12.05.

Minderop, Albertine. 2011. Psikologi Sastra. Jakarta: Obor Indonesia

Rahmanto, B. \& Dick Hartoko. 1986. Pemandu di Dunia Sastra. Yogyakarta: Kanisius.

Ratna, Nyoman Kutha. 2013. Teori, Metode, dan Teknik Penelitian Sastra. Yogyakarta: Pustaka Pelajar. 
Mujihadi, Analisis Kondisi Psikoseksual Tokoh Waras...(hal 275-289)

Sudikan, Setya Yuwana. 2015. "Pendekatan Interdisipliner, Multidisipliner, dan Trandisipliner dalam Studi Sastra". Nurhadi, Didik (Eds). Prosiding Seminar Nasional Paramasastra 3. Fakultas Bahasa dan Seni Universitas Negeri Surabaya.

Tohari, Ahmad. 2011. Ronggeng Dukuh Paruk. Jakarta: Gramedia Pustaka Tama.

Wiyatmi. 2011. Psikologi Sastra:Teori dan Aplikasinya. Yogyakarta: Kanwa Publiser. 